(C) 2017

Ласло О. О., кандидат сільськогосподарських наук, Диченко О. Ю., кандидат сільськогосподарських наук Полтавська державна аграрна академія

\title{
ВИКОРИСТАННЯ ТЕХНОЛОГІЙ ТОЧНОГО ЗЕМЛЕРОБСТВА ТА РОСЛИННИЦТВА ПІД ЧАС ВИЗНАЧЕННЯ ЕКОЛОГІЧНО СТАБІЛЬНИХ ТЕРИТОРІЙ ДЛЯ ОРГАНІЧНОГО ВИРОБНИЦТВА
}

\section{Рецензент - доктор сільськогосподарських наук, професор П. В. Писаренко}

У статті розглянуто доияільність та необхідність використання технологій точного землеробства в разі виділення екологічно стабільних територій для виробництва органічної продукиії. Наведені результати досліджень доводять, шо для зниження витрат на отримання одинииі якісної сільськогосподарської продукції та зменшення навантаження на навколишнє середовище створюються й використовуються точні технології на базі агрономічної системи урожайності. Для досягнення мети необхідно чітко встановити критерї та екологічні еталони для територій, враховуючи не лише характеристики грунтів, але й антропогенний вплив. Поєднання нових наукових технологій та останніх досягнень в аграрній галузі дає змогу розробити систему точного виробництва, як комплекс заходів вдосконалення процесів землеробства й рослинництва, основним завданням яких є виділення екологічно стабільних сировинних зон для виробництва органічної продукиії.

Ключові слова: точне землеробство, ГІСтехнологіі, система глобального позиціювання, агротехнології точного виробництва, системи GIS, сировинні зони, органічна продукиія, екологічно стабільні території.

Постановка проблеми. Концепція сайтспецифічного управління сільськогосподарськими площами - практика точного землеробства, заснована на оптимальному використанні ресурсів для покращання родючості грунтів. При цьому рішення можуть прийматись як для реагування та корегування часових змін у межах вегетаційного періоду, так і для підвищення ефективності виробництва в цілому $[4,3,1]$.

Аналіз останніх досліджень і публікацій, у яких започатковано розв'язання проблеми. Перед суспільством в усі часи виникала проблема раціонального використання природних ресурсів, у тому числі й земельних, вирішення якої давало б змогу максимально задовольнити матеріальні та духовні потреби людства. Сучасне використання земельних ресурсів не відповідає вимогам раціонального природокористування.
Порушено екологічно допустиме співвідношення площ ріллі, природних кормових угідь, лісових насаджень, що негативно впливає на стійкість агроландшафтів [5]. Тому системи точного землеробства отримують усе більше визнання $\mathrm{i}$ розповсюдження під час дослідження сільськогосподарських територій. Вони базуються на новому погляді на сільське господарство, за якого поле, неоднорідне за рельєфом, грунтовим покривом, агрохімічним вмістом, потребує застосування на кожній ділянці окремих агротехнологій [2].

Впровадження технологічної й технічної новизни у сільськогосподарське виробництво має здійснюватися шляхом системного аналізу технологічних процесів із визначенням їх економічної ефективності [6].

Тактика й стратегія агротехнологій точного виробництва, визначення оптимальної норми поживних речовин у грунті для оптимального росту і розвитку рослин на всіх стадіях вегетації базуються на концепції, що агрохімічний склад грунту $є$ індикатором його родючості й потребує першочергової уваги [5].

Технологія точного землеробства під час виділення екологічно стабільних сировинних зон повинна включати наступні етапи:

- створення електронних карт полів;

- створення бази даних по полях (площа, урожайність, агрохімічні та агрофізичні властивості (фактичні i нормативні), рівень розвитку рослин);

- проведення аналізу у програмному забезпеченні та подання наочних форм для розробки рішень;

- подання команд із прийнятих рішень на чіпкартах, які завантажуються у технічні пристрої на сільськогосподарські агрегати для проведення диференційованої обробки рослин [2].

Для роботи за технологією точного землеробства необхідно провести внутрішньогосподарський землеустрій в аграрному підприємстві; відібрати сівозмінні площі для застосування систем 


\section{СІЛЬСЬКЕ ГОСПОДАРСТВО. РОСЛИННИЦТВО}

точного землеробства, як ті, які найінтенсивніше використовуються; розбити поля на робочі ділянки - ділянки правильної форми, однакового розміру, зручні для обробітку агрегатами, що мають власні номери і вважаються однорідними елементарними ділянками 3 просторовою прив'язкою до місцевості; відібрати грунтові проби 3 просторовою прив'язкою до місцевості; визначити вміст поживних елементів по кожній одиниці управління й розробити карту розподілу агрохімічних показників; обробити, проаналізувати за допомогою програмного забезпечення $\mathrm{i}$ скласти технологічну карту диференційованого внесення добрив $[2,6]$.

Основа точних технологій звужує його сутність до управління своєчасним втручанням у процес вирощування сільськогосподарських культур із тим, аби зробити це управління більш контрольованим.

Метою досліджень $є$ розробка стратегії цілісного управління земельними ресурсами із використанням інформаційних технологій, що спрямована на удосконалення виробництва і мінімізацію впливу на довкілля та виділення екологічно стабільних територій для ведення органічного виробництва.

Завданням агротехнологій точного виробництва є отримання високих врожаїв сільськогосподарських культур із мінімальними витратами на підвищення родючості грунту, захист рослин від бур'янів, хвороб і шкідників та на підживлення рослин добривами.

Результати досліджень. Системи точних технологій отримують усе більше визнання і розповсюдження в Україні. Їх мета - підвищення виробництва якісної сільськогосподарської продукції та збереження навколишнього середовища.

Системи точних технологій, що використовуються у сільськогосподарському виробництві, мають низку складових, із яких підсистеми точного землеробства і точного рослинництва.

Інформація про точні технології $\epsilon$ найціннішим ресурсом сільгоспвиробника, оскільки вона важлива на всіх етапах сільськогосподарського виробництва. Її складовою $\epsilon$ : характеристика культур; агрофізичні та агрохімічні властивості грунту; видовий склад шкідливих об'єктів агрофітоценозу; вимоги щодо внесення добрив; динаміка урожайності тощо.

Нині у світі відбувається швидкий розвиток нових технологій: розроблена низка комп'ютерних програм, у тому числі електронні таблиці, бази даних, географічні електронні системи та інші види прикладного програмного забезпечення. Система глобального позиціювання
(GPS) дає можливість визначити конкретне місце на полі з точністю до кількох сантиметрів.

Існує чимало спеціальних датчиків, які можуть відображати стан і характеристику грунту, стан посівів, процес збирання, видаючи дані, що використовуються для корекції чи контролю певної операції.

Завданням даних підсистем точного землеробства $є$ : моніторинг і контроль використання техніки (GPS, ГЛОНАСC); автоматичний моніторинг урожайності і складання карт урожайності полів; складання грунтових карт із використанням автоматичних грунтовідбірників; можливість вносити необхідну кількість добрив, насіння на різні ділянки одного й того ж поля; спостереження за динамікою процесів на основі накопичення, збереження і наочності зібраних даних; відслідковування зміни стану полів і посівів на різних ділянках, що допомагає визначити послідовність їх обробітку; багатофакторний аналіз i візуалізація зібраних даних тощо. На рис. 1 подано схему функціонування точних систем виробництва, а саме:

підсистема точного землеробства, 3 нашого погляду, включає:

- організацію первинного обліку фактично використаної ріллі за допомогою GPSтехнологій i пристроїв високоточної навігації, паспортизації полів, створення електронних карт полів, агрономічний облік по кожному полю i робочій ділянці;

- проведення агрохімічного обстеження полів за допомогою автоматичних грунтовідбірників i спектрометричний лабораторний аналіз;

- проведення моніторингу земель (поточний, щорічний, облік змін розміру землекористування і структури посівних площ).

Підсистема точного рослинництва включає:

- складання проекту землеустрою підприємства (вибір сівозмінних площ під застосування органічних технологій вирощування сільськогосподарських культур, розміщення кормових i спеціальних сівозмін);

- оптимізація системи удобрення на заплановану урожайність на основі дослідження агрохімічних властивостей грунтів.

У залежності від біологічних вимог сільськогосподарських культур, отриманих на основі результатів польових i лабораторних обстежень i розрахунку даних, вноситься диференційована (відносно розробленої грунтової карти і розташування на місцевості) норма елементів живлення. Таким чином досягається оптимізація живлення культур і вирівнювання урожайності відповідно різних ділянок поля. 


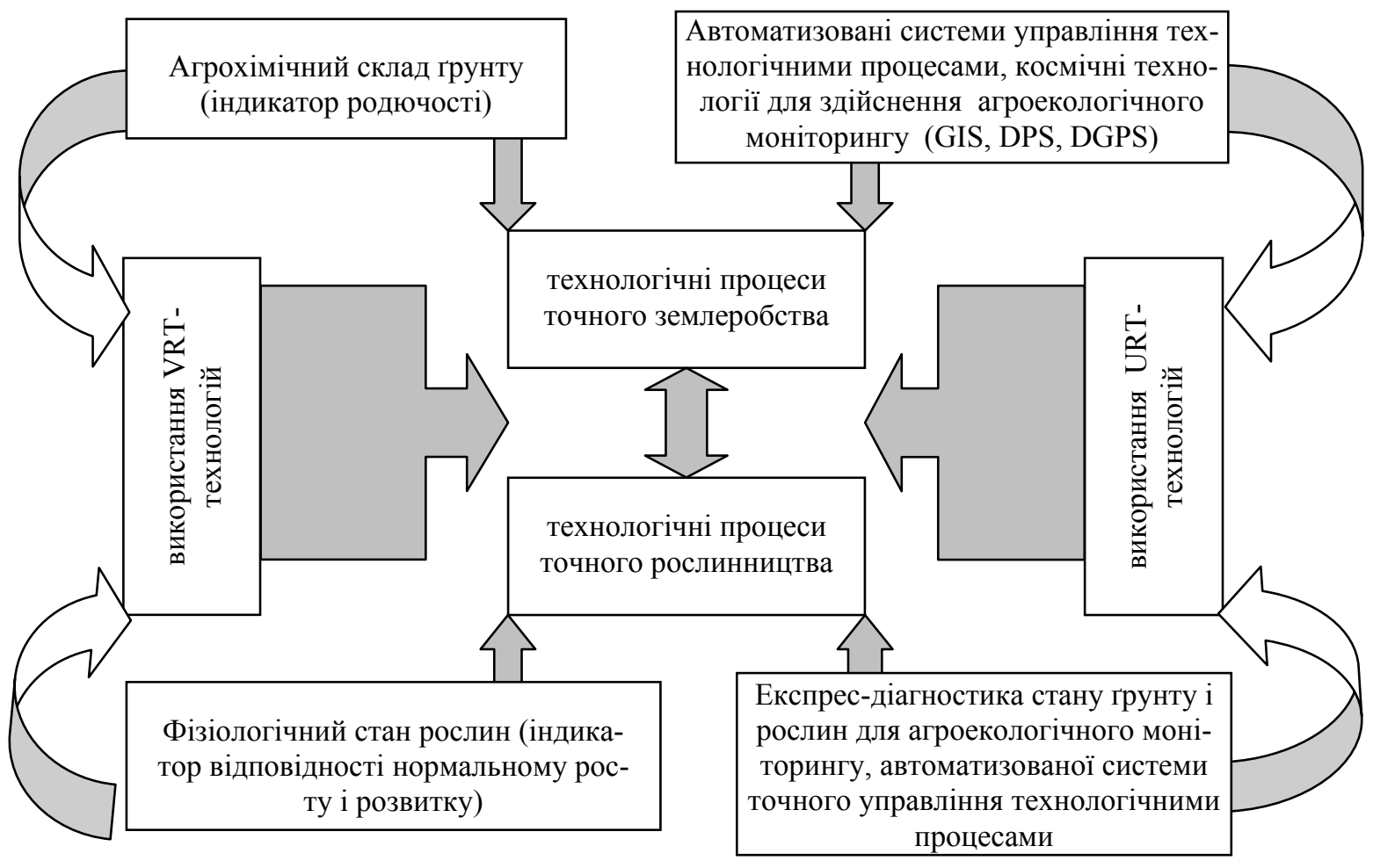

Рис. 1. Схема функціонування підсистем точного виробництва [розробка автора на основі джерел 4, 6]

Це забезпечує економію добрив, підвищення урожайності та якості сільськогосподарської продукції, а також створює умови для збереження навколишнього середовища. Крім того, зниження антропогенного навантаження на агробіоценози підвищує стійкість останніх, даючи змогу отримати додатковий приріст урожаю за рахунок біологічних факторів.

Висновок. Комплексний підхід до технологій точного землеробства повинен охоплювати всі етапи сільськогосподарського виробництва, починаючи 3 планування і закінчуючи післязбиральною підготовкою. Збір даних, їх обробка, менеджмент і технологія ведення сільськогосподарської діяльності сприяють підвищенню його

\section{БІБЛІОГРАФІЯ}

1. Болотова T. Н. Анализ агроэкономической модели точных технологий в растениеводстве / Т. Н. Болотова // Вісник ХНТУСГ. - 2007. - Вип. 49. - C. 76-83.

2. Использование технологий точного земледелия в сельскохозяйственном производстве как один из путей его инновационного развития [Электронный pecypc]. - Режим доступа : http://eurotechnika.ru/content/ispolzovanie (2016).

3. Лисогоров К. С. Прикладні аспекти реалізації системи точного землеробства / К. С. Лисогоров, С. К. Міхеєв // Таврійський науковий вісник : зб. наук. праць. - Херсон : Айлант, 2004. - Вип. ефективності, якості продукції, раціональному використанню засобів захисту рослин і добрив, економлячи енергоресурси й забезпечуючи захист навколишнього середовища від техногенного впливу.

Економічним обгрунтуванням використання точних технологій є: повне використання потенціалу рослин, економія внесення засобів захисту $\mathrm{i}$ добрив, економія від скорочення кількості проб у ході точкового агрохімічного аналізу грунту, економія витрат на насіння. Ці показники дають можливість не тільки окупити придбання GPSприладів за 2-3 роки, а й отримати значні прирости урожаю сільськогосподарських культур високої якості.

\section{3. - C. 271-277.}

4. Сучасна класифікація точних агротехнологій / [Лісовий М. П., Медведєв В. В., Болотова Т. М. та ін.] // Вісник аграрної науки, 2004. №4. - C. 45-48.

5. Сохнич А. Я. Ландшафтно-екологічні аспекти управління земельними ресурсами [Текст] / А. Я. Сохнич, Л. М. Тібілова // Економіка АПК. 2006. - №5. - С. 27-28.

6. Точное земледелие, новые технологии в сельском хозяйстве [Электронный ресурс]. - Режим доступа : http://eco-razum.com/about/tochnoezemledelie-tehnologii.php. 